\title{
TRADUZINDO VERBOS DE MOVIMENTO DO INGLÊS PARA O PORTUGUÊS: LÉXICO E CONSTRUÇÕES
}

\author{
Heronides Moura ${ }^{1}$ \\ Lucas Badaracco 2 \\ 1 2-Universidade Federal de Santa Catarina, Florianópolis, Santa Catarina, Brasil
}

\begin{abstract}
Resumo: Neste artigo, investigamos as implicações tradutórias do uso de verbos movimento no inglês e no português brasileiro (PB) à luz da Linguística Cognitiva a partir de narrações de partidas de basquetebol: um corpus que constitui um contexto natural de realização da língua falada. Analisamos duas partidas da National Basketball Association (NBA). Em total, foram compiladas 104 ocorrências de verbos de movimento, 51 em inglês e 53 em PB. Quanto aos tipos, foram constatados 46 diferentes em inglês e 26 em PB. Isso sugere que as narrações são mais ou menos equivalentes no que concerne ao estilo narrativo, pois ambas usam uma quantidade parecida de verbos. Entretanto, tem-se uma assimetria em relação à variedade de verbos de movimento empregados e à sua semântica. Enquanto no inglês há maior variedade de verbos de movimento, no PB ela é menor. Nesta língua, por sua vez, a preferência são verbos de movimento menos específicos, que indicam DIREÇÃO, sem muitas informações de MODO. Tais diferenças são a fonte das dificuldades da tradução de verbos de movimento, do inglês para o português. No que concerne aos estudos da tradução, esta pesquisa corrobora a Hipótese do Item Único, segundo a qual um item é único para uma dada língua, se os contextos gramaticais em que ele aparece são únicos daquela língua.
\end{abstract}

Palavras-chave: Tradução; Verbos; Movimento; Tipologia

\section{TRANSLATING MOTION VERBS FROM ENGLISH TO PORTUGUESE: LEXICON AND CONSTRUCTIONS}

Abstract: Based on Cognitive Linguistics, we investigate the use of motion verbs in English and Brazilian Portuguese basketball broadcasts 
and its implications for translation. This corpus, which represents a natural context of spoken language, included two National Basketball Association games. We found a total of 104 motion verb occurrences, 51 in English and 53 in Brazilian Portuguese, consisting of 46 different types in English and 26 in Brazilian Portuguese. This suggests that the broadcasts are somewhat equivalent in style, since a similar number of verbs were used in both languages. However, the variety of motion verbs and their meaning were asymmetrical. A wider variety of motion verbs is used in English than in Brazilian Portuguese. Moreover, in English, there is a tendency to use verbs that encode MANNER in the verb root. In Brazilian Portuguese, on the other hand, the preferred verbs are less specific, encode PATH and provide less information about the manner of motion. Such differences are the source of the difficulties for translating motion verbs from English to Portuguese. For translation studies, this study corroborates the Unique Items Hypothesis, according to which an item is unique in a given language inasmuch as its grammatical contexts are unique in that language.

Keywords: Translation; Verbs; Motion; Typology

\section{Introduction}

This paper represents an attempt to analyze problems in the translation of motion verbs. To do this, we compared the way motion is represented in English and Brazilian Portuguese (BP), using a very specific corpus: basketball broadcasts. The analysis of this corpus reveals difficulties that different modes of representing motion cause in translation, especially from English to BP. It is assumed that "typological findings could improve the understanding of what happens in the process of translation in different contexts" (Filipovic, 2008, p. 26).

The corpus consists of National Basketball Association (NBA) telecasts in American English and Brazilian Portuguese. The games were from the 2018-2019 regular season, which were accessed through the league's official online broadcast service, NBA League Pass (watch.nba.com). Further detail about the corpus is provided in section 3 below. 
Sentences such as the example below (1) are common in basketball broadcasts:

(1) Despite him shooting from point-blank range, the ball rimmed out.

In this example, two actions are expressed by two verbs: the player's throw ([...] him shooting from point-blank range) and the striking of one inanimate object against another (the ball rimmed out). The particle out indicates a third action: the ball's subsequent exit. In BP, one possible translation for sentence (1) could be:

(2) Apesar de ele arremessar de muito perto, a bola bateu no aro e saiu.

Unlike (1), there are three verbs in (2): the player's throw, the ball hitting the rim and the ball's subsequent exit. Likewise, in varieties of Latin American Spanish, it would be acceptable to say:

(3) A pesar de tirar de muy cerca, la pelota pegó en el aro y salió.

The same elements are present in (2) and (3) because, although they are two distinct languages, BP and Spanish are part of the same typological family regarding the expression of motion. Slobin (1996a) calls this group verb-framed languages, or V-languages. On the other hand, English belongs to a group of satellite-framed languages, or S-languages. V-languages prefer verbs that indicate the direction of the motion, with the manner of motion being expressed by subordinate clauses, while S-languages prefer verbs that convey the manner of motion, with particles (or satellites) that express trajectory or direction. In the BP and Spanish examples above, the 
verbs sair/salir encode the direction of motion of the ball (outward). In the English example, the direction is not indicated by the verb, but by the particle 'out', which is attached to the verb 'to rim'.

The differences in these examples are not limited to the lexical expression of motion, but also involve the domain of morphology, especially derivation. Aronoff and Fudeman (2011) explain the peculiarities of 'zero-derivation' in English: this abstract word formation process gives rise to lexemes whose interpretation is heavily context-dependent. According to these authors, verbs formed by zero-derivation have a wide range of meanings: 'to sand', for example, can refer to polishing with sandpaper as well as to spreading, covering or filling with sand. The creation of verbs (neologisms) through this process is common; for example, sentence (4):

(4) He wristed the ball over the net.

[Ele jogou a bola por cima da rede com um toque do pulso]

The English noun 'wrist' would be translated as pulso in BP; and the verb 'to wrist' would mean to hit or propel with the wrist. Although the relationship seems simple, there is nothing in the verb that allows one to infer 'hit' outside its linguistic context ('wrist the ball'). That is to say, decontextualized, to wrist could very well mean putting something on the wrist or squeezing with the wrist. Case (4) occurred during a tennis broadcast, which means that the contact between ball and wrist was mediated by an instrument (a racket).

This strategy of word formation in English is relevant to the topic we are discussing in this paper, since in (1) we have a zeroderivation (rim - 'to rim'). The noun 'rim' can be translated as aro in BP and the verb 'to rim' as bater/atingir o aro. Thus, there are two main factors, both grammatical in nature, that distinguish English motion verbs from those in Portuguese: preferences in 
grammatical composition for expressing motion and morphological patterns. These distinct morphosyntactic structures direct the translation choices from English to BP.

\section{Different typological patterns in the expression of motion: translation difficulties}

Regarding what is understood by motion, the perspective used here aligns with that of Talmy $(\mathrm{A}, \mathrm{B}, \mathrm{C})$ and Slobin $(\mathrm{A} ; \mathrm{B} ; \mathrm{C}$; $\mathrm{D} ; \mathrm{E} ; \mathrm{F})$. In the literature on the lexicalization of motion, two broad classes of verbs are assumed: those that express PATH and those that express MANNER. The former encode the direction of motion, such as enter (entrar), exit (sair), go (ir), or return (voltar); the latter only express the way motion occurs, such as run (correr), jump/leap (pular), swim (nadar) or fly (voar), without specifying direction or trajectory. It should be noted that entering and exiting do not encode MANNER, and thus combinations such as entrar correndo (running in) or sair caminhando (walking out), in which the gerunds convey MANNER, are common in BP. On the other hand, since correr (run) or pular (jump) do not involve information about $\mathrm{PATH}^{1}$, grammatical constructions such as correr para trás (run backward) or pular para a frente (leap forward) also become necessary.

Although these patterns are regular, even superficial observation of normal spoken language demonstrates that they do not exclude other construction types. For example, it is common for BP speakers to use combinations such as entrar para dentro (enter in) or subir para cima (climb upwards), in which direction is already implicit in the verbs (entrar and subir) but is made explicit (i.e. redundant) in the directional particles (dentro and cima). That is, the typology of motion expression patterns does not imply that

\footnotetext{
${ }^{1}$ As is usual in the literature, we will use uppercase to represent the semantic primitives involved in the conceptual structure of motion.
}

Cad. Trad., Florianópolis, v. 39, n 2, p. 166-183, mai-ago, 2019. 
distinct typological patterns cannot coexist in the same language (Beavers et al.; Moura; Silva Jr.; Santos Filho; Santos Filho,). Such coexistence can be seen in the examples from Beavers et al. (367) below:

(5a) John moved stealthily out of the bedroom.

(MANNER = adverb, PATH = adposition)

[João saiu do quarto sorrateiramente ${ }^{2}$ ]

(5b) John stole out of the bedroom.

(MANNER $=$ verb, PATH $=$ adposition)

[João esgueirou-se do quarto]

(5c) John left/exited the bedroom stealthily.

$(\mathrm{PATH}=$ verb, $\mathrm{MODE}=$ adverb $)$

[João saiu do quarto sorrateiramente]

The above examples show that several types of grammatical and lexical patterns allow the expression of motion in English. PATH can be expressed by adpositions (in this case, the particle 'out'), as in (5a) and (5b), or directly in the verb, as in (5c). MANNER, however, can be expressed either by an adverb (stealthily), as in (5a) and (5c), or directly by the verb, as in (5b).

The fact that different patterns coexist within a particular language does not imply that it has no preferential pattern. In English, the most usual form (Slobin (C)) is that which appears in sentence (5b), where MANNER is expressed by a verb and PATH is expressed by a particle. It is this dominant character of a certain pattern that justifies Talmy's (A) typology, which we will now discuss.

Talmy distinguishes two major domains regarding the expression of motion: the domain of meaning and the domain of

2 Translated by the authors.

Cad. Trad., Florianópolis, v. 39, no 2, p. 166-183, mai-ago, 2019. 
surface expression. The concepts associated with the first domain are MOTION, PATH, FIGURE, GROUND, MANNER and CAUSE, while verb, adposition, subordinate clause, and satellite are associated with the second. Surface elements serve to express those of meaning, although the relation is not always univocal.

According to Talmy (A: 57), there is a limited number of possible typological patterns for the expression of motion. However, a further question is whether a language exhibits only one pattern or a mixture of patterns. In a recent study on BP, Santos Filho (2018) focused on motion verbs with the primitive MANNER $^{3}$, using Twitter as a database. Unlike Talmy (B), Slobin (G), and Levin and Rappaport (2014), this author found that verbs expressing MANNER in their root are neither restricted nor unusual in BP. Thus, BP does not completely fit into the V-language class, as proposed by Talmy (B) and reinforced by Slobin (A; B; $\mathrm{C} ; \mathrm{D} ; \mathrm{E} ; \mathrm{F}$ ) since it includes verbs of motion that lexicalize (a) MANNER, PATH or FIGURE, (b) MANNER and PATH, and (c) MANNER and FIGURE. Such transitions between different patterns indicates that $\mathrm{BP}$ is not restricted to one. These results are relevant in that they help deconstruct the idea that languages have only one dominant typological pattern. In fact these patterns are not mutually exclusive; a linguistic system, depending on the context, can behave more like a V-language or an S-language.

However, the coexistence of different patterns in the same language does not imply that translating English into a typologically distinct language such as $\mathrm{BP}$ is an easy matter. One of Talmy's (A, B, C) and Slobin's (A, B, C, D, E, F) most important points is that certain typological patterns impose more usual and colloquial forms, a rhetorical style proper to each language regarding the expression of motion.

Although Santos Filho (2018) identified a large number of BP verbs that encode the MANNER of motion, certain grammatical

${ }^{3}$ Among dozens of other types, Santos Filho (2018) lists verbs such as coxear, debandar, desabalar, desembestar, disparar, engatinhar, escafeder, escapulir, esgueirar-se, etc.

Cad. Trad., Florianópolis, v. 39, nº 2, p. 166-183, mai-ago, 2019. 
patterns typical of S-languages are in fact more common in English than in Portuguese. Among these patterns, the presence of multiple segments, such as prepositions or adverbs, linked to a single verb is a feature of English but not Portuguese.

One way to interpret these facts is to say that certain constructions occur more frequently in S-languages (such as English) than in V-languages (such as Portuguese). Therefore, the difference between these typological patterns is perhaps not a difference of lexical character but constructional character (Goldberg), which includes morphosyntactic structures, such as the previously mentioned zero-derivation.

These different repertoires, built into to each language through specific preferred rhetorical styles, are a source of translation difficulties. For example, English sentences expressing motion tend to mark the MANNER of motion, whereas translations in Portuguese (as in V-languages in general) tend to omit this (Slobin, F; Cappelle; Moura; Berger). When translating an English sentence, such as (6) below, the translator must make choices about how to organize information about the PATH and the MANNER of the motion in Portuguese and about what distinctions in the original should be maintained in the target language (Slobin, F). The translation that Slobin quotes (F: 05) is presented below in (7):

(6) He still wandered on, out of the little high valley, over its edge, and down the slopes beyond. ${ }^{4}$

(7) Continou avançando, saiu do vale alto e estreito, e desceu as ladeiras além. ${ }^{5}$

${ }^{4}$ Slobin (2005) compared different translations of The Hobbit.

${ }^{5}$ The Hobbit was translated to BP by L. M. R. Esteves and A. Pisetta ( $O$ hobbit. São Paulo: Martins Fontes, 1995). 
The Portuguese translation omits MANNER, as well as one of the segments that represent PATH.

Slobin (B) emphasizes that such preferences affect translations from an S-language to a V-language and vice versa. That is, it is the typological patterns of the involved languages that influence the translation choices, not the idiosyncrasies of a single language. Thus, similar results appear in Spanish, which is also a V-language. Sentences like "He stomped from the trim house" and "The three women drifted inertly down the hot street" have been translated, respectively, as "Salió de la pulcra casa" and "Las tres mujeres siguieron, pausadamente, calle abajo" (Slobin: B). Whereas 'stomp' and 'drift' are verbs that encode a manner of motion, salir and seguir do not do so by themselves. There are indications that the same occurs with PATH: translations into Spanish usually omit some details and specifications present in English-language originals (SLOBIN, B).

An interesting point is that $\mathrm{V}$-languages tend to eliminate expression of the MANNER of motion when it can be easily inferred from the context (Papafragou et al; Beavers et al). Thus, for example, a sentence describing the act of climbing a ladder, whose type of motion is clearly inferable, would not have adverbial adjuncts unless there was something unusual about the motion (e.g. the difference between $O$ menino subiu a escada (The boy climbed the ladder) and $O$ menino subiu a escada aos pulos (The boy climbed the ladder by leaps and bounds). From this perspective, sentences with and without adverbial adjuncts would correspond to the marked and unmarked forms in V-languages, respectively. In theory, therefore, translations in V-languages only mark the MANNER of motion if this circumstance is very relevant.

This is also interesting for translation theory and it leads us to situate this study within the unique-item hypothesis (Cappelle). According to this hypothesis, an item is unique to a given language if the grammatical contexts in which it occurs are specific to that language. English motion verbs, such as 'drift' (vagar, andar sem destino) have correlates in the BP lexicon. Thus, the idea is that MANNER verbs like 'drift' are unique because they occur in 
grammatical constructions specific to English, such as those that are being described in this paper. Manner verbs like 'drift' are not lacking in BP; what is lacking is the set of constructions linked to such verbs. The lack of similar unique items in BP is the real source of difficulty when translating motion events from English.

\section{Data analysis and discussion}

The data discussed here were taken from two 2018-2019 regular season NBA games, one broadcast in English and the other in BP, which were accessed through the league's official online broadcast service, NBA League Pass (watch.nba.com) ${ }^{6}$ In total, 104 instances of motion verbs were found in the two broadcasts, 51 in English and 53 in Portuguese, including 46 different verb types ${ }^{7}$ in English and 26 in Portuguese. Although the official duration of NBA games is 48 minutes, interruptions due to fouls, free throws, time outs, etc. stretched the complete broadcast to 96 minutes, and all of the audio was considered in the analysis. It should be noted that these specific games were selected because the final scores were close (less than 10 points), thus ensuring constant commentary, which is not always the case during so-called "garbage time" 8 .

\footnotetext{
${ }^{6}$ The games were the Dallas Mavericks vs. the Los Angeles Clippers (January 22, 2019 in English) and the Philadelphia 76ers vs. the San Antonio Spurs (January 23, 2019 in Portuguese).

${ }^{7}$ In this paper, 'verb type' indicates a lexical root

${ }^{8}$ This expression has no equivalent in Portuguese: "garbage time" is when the outcome has already been decided and the coaches take the starters out of the game. In such cases, it is common for sportscasters to describe the action less attentively, since nothing will change the final result.
}

Cad. Trad., Florianópolis, v. 39, nº 2, p. 166-183, mai-ago, 2019. 
Figure 1: Distribution of motion verbs in English and Portuguese broadcasts

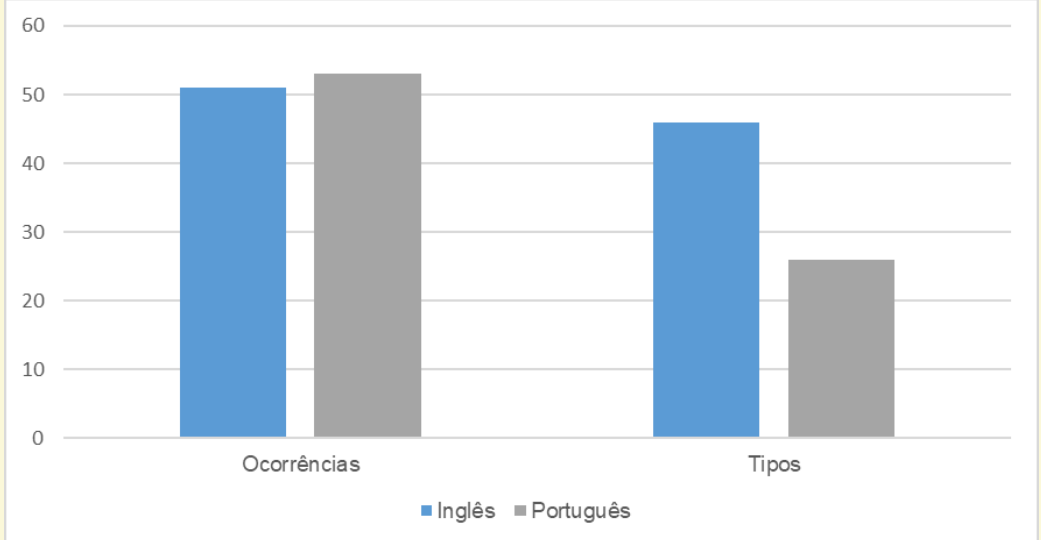

What first stands out in the broadcasts (Figure 1) is the parity between the total occurrences of motion verbs in both languages: 51 in English and 53 in Portuguese. This suggests, at first glance, that there was little variation in narrative style, despite the fact that the two languages are from distinct typological families and that basketball is far less traditional in Brazil than the USA. On the other hand, the variety of verbs was asymmetrical: 46 types in English vs. 26 in Portuguese. There is evidence that this issue is not due to a limited Portuguese lexicon. According to Santos Filho (2018), BP includes a wide variety of verbs expressing MANNER of motion in the verbal root. The discrepancy does not consist in what each language can say, but in how it is said. We will discuss some examples below to clarify this.

(8) He almost tipped it away from Harris.

[Ele quase cutucou ela [a bola] para longe de Harris].

(9) Harrell able to tip the rebound right back in. [Harrell consegue desviar o rebote para dentro.] 
Sentence (8) shows a canonical S-language strategy: a main verb expressing MANNER of motion (to tip), a particle indicating PATH (away) and complementary information about the SOURCE (from Harris). ${ }^{9}$ In (9), although the verb form (to tip) is the same in as (8), the particle (in), and consequently the action, is different. While in (8) the ball is in Harris' possession and the agent (he) almost diverts it, in (9) no one has possession of the ball, since it is a rebound, and the agent (Harrell) puts it in the basket (tip in).

In addition, the motion in these examples is not explicit: when looking only at the linguistic data, the 'tip away' in (8) could have been in any direction (the ball in Harris' possession may be above or below the agent's arm, making the motion vertical, or at the same level of the arm, making the motion horizontal). However, the 'tip in' used in (9) is a bottom-up move, since the ball hits the rim and the player is either on the court floor or jumping up from it. Thus, combining the same verb with different particles allows for varied inferences and meanings.

Other cases of interest, such as (10) and (11) below, are related to zero-derivation of motion verbs from nouns:

(10) Harrison Barnes banked it home with the foul. [Harrison Barnes jogou a bola na tabela, fez a cesta, mais a falta.]

\section{(11) Got to post him up.}

[Tem que jogar de costas contra ele. / Tem que fazer o post up.]

In (10) the verb 'to bank' could very possibly have originated from the expression 'bank shot', in which the backboard is used to angle the shot into the hoop. Thus, it is understood that in (10) the

${ }^{9}$ SOURCE is a subdomain of PATH. 
agent (Harrison Barnes) bounced the ball off the backboard prior to scoring ('home' serves as an outcome in this case). In (11), the verb 'to post up' appears, which is derived from the expression 'post up', i.e. an offensive strategy where a player advances in the lane ("the low post") with his back toward both the defender and the basket, which generally gives him a physical advantage. Thus, the context of (11) refers to inequality: a smaller player on defense against a larger player on offense. 'Got to post him up' is advice for the larger player on offense to take advantage of the size mismatch with a smaller defender. It should be pointed out that in both cases, such verbs could be coined due to English morphology and the grammatical strategies it entails.

However, in BP, although noun-verb derivation exists, e.g., the verb garfar from the noun garfo (fork) or the verb carimbar from the noun carimbo (rubber stamp), the word formation process is more restricted than in English. Thus, the manner-of-motion verbs in sentences (10) and (11) could not be used so specifically in BP, as can be seen in our translations.

The translation of 'bank home' breaks the expression into two verbs: shoot the ball at the backboard (jogar a bola na tabela) and make a basket (fazer a cesta). In the translation of (11), an alternative is created by combining the polysemic verb fazer with an Anglicism (a common strategy by Brazilian sportscasters). ${ }^{10}$ However, in terms of morphology, BP provides a further type:

(12) [O jogador] levou um tocaço. ${ }^{11}$

What happens in (12) is an augmentative of the noun toco (block): tocaço (a great/impressive block). Although English has the verb 'to block', which is derived from the noun 'block', an

\footnotetext{
${ }^{10}$ That is, a combination of fazer + noun (whether an Anglicism or not) appears with some regularity: fazer o break, fazer a finta, fazer a remada, fazer a definição. ${ }^{11}$ This example was drawn from the corpus.
}

Cad. Trad., Florianópolis, v. 39, nº 2, p. 166-183, mai-ago, 2019. 
alteration to the noun toco is needed to provide emphasis (12). Let us look at other BP examples found in the corpus:

(13) Mills se desloca, serve o Belinelli.

[Mills changes position, passes to Belinelli]

(14) Avança Rudy Gay.

[Rudy Gay advances]

Note that even with the use of motion verbs in (13) and (14), the actions are not very informative about the scenes themselves. We know that in (13) Mills se desloca (changes position/moves), and although we imagine that he is running, this is not explicit, nor are we sure whether this process happened quickly or slowly. In addition, he passes to Belinelli, his teammate, but the narration does not specify, for example, whether the exchange was a throw or a hand-off. Likewise, in (14), the agent (Rudy Gay) advances, and we assume that he is in possession of the ball, running, but this information is all inferred if we only hear the audio, the linguistic data. Occurrences in which the main motion verbs do not specify MANNER are frequent in the corpus. ${ }^{12}$ As we have seen, descriptions of motion that do not specify MANNER are the most common and the least marked form of V-language expression (Papafragou et al.; Beavers et al.).

Less specific actions (deslocar-se, servir, avançar) would be to more specific actions (correr [run], passar [pass], caminhar [walk]) as superordinate categories are to basic-level categories in Rosch's (1978) categorization theory. The more comprehensive a category, the less informative it is (Rogers and McClelland). A comparison of the following sentence (15) in BP and English will clarify this point:

${ }^{12}$ Servir: three occurrences; deslocar-se: four occurrences; avançar: five occurrences.

Cad. Trad., Florianópolis, v. 39, no 2, p. 166-183, mai-ago, 2019. 
(15) Dennis Smith Jr. [...] running right by everybody.

This sentence includes the verb 'to run' (correr), as well as a particle that confers a more specific meaning to the action: 'by'. Thus, 'To run right by everybody' informs the listener that the agent (Dennis Smith Jr.) advanced quickly with no interference. Constructions such as this could be considered uniquely English (Cappelle). In short, English grammatical constructions allow a wide range of specifications for motion, generating categorizations at the basic level (e.g. running, passing, walking), or even at the subordinate or hyponymic level (Lakoff, Johnson), such as 'to run right by everybody'. BP tends to represent superordinate categories of motion, such as deslocar-se (change position), servir (pass) or avançar (advance), leaving the identification of more specific traits to the context.

\section{Final considerations}

In this article, we have analyzed the expression of motion in English and BP based on data from basketball broadcasts, and the different options available to translators. The data, which is from a larger project, indicated some interesting trends and provided greater detail about each language system. We found that although the number of motion verb occurrences was similar in both languages ( 51 verbs of motion in English and 53 in BP), the verb types varied broadly (46 in English and 26 in BP). This suggests that the broadcasts are roughly equivalent in narrative style, due to the similarity in total occurrences, but there is asymmetry regarding the variety of motion verbs and their semantics, since English featured a greater variety of verbs than BP. We also determined that the English broadcast involved verbs whose roots express MANNER, a canonical strategy in S-languages, as well as the relevance of zero-derivation in some motion verbs that have 
no correlates in BP. In the BP broadcast, there was a preference for less specific motion verbs that indicate PATH (avançar, vir, chegar) but little about MANNER. In the morphology domain, although zero-derivation is not used to form manner verbs in BP as it is in English, suffixation allows very specific actions to be expressed, such as tocaço, chutinho or golaço.

We can conclude that, although lexicalization patterns are an important factor in typological differences, the determining factor in the representation of the motion is the distinct repertoires of grammatical construction in the two languages, which have important effects on translation from English to Portuguese.

\section{References}

Aronoff, M.; fudeman, K. What is Morphology? 2a ed. Hoboken: WileyBlackwell, 2011.

Beavers, J; Levin, B.; Tham, S. W. The typology of motion expressions revisited. Journal of Linguistics, vol. 46, N. 2, p. 331-377, 2010.

Cappelle, B. English is less rich in manner of motion verbs when translated from French. Across Languages and Cultures 13 (2), p. 173-195, 2012.

Filipovic, L. Typology in action: applying typological insights in the study of translation. International Journal of Applied Linguistics. Vol. 18-1, 2008, p. 23-40.

Goldberg, A. Constructions: A construction grammar approach to argument structure. Chicago: The University of Chicago Press, 1995.

Lakoff, G.; Johnson, M. Women, fire and dangerous things: what categories reveal about the mind. Chicago: The University of Chicago Press, 1987.

Cad. Trad., Florianópolis, v. 39, no ${ }^{0}$, p. 166-183, mai-ago, 2019. 
Levin, B.; Rappaport, M. "Manner and Result: A View from clean". In: Pensalfini, R.; Turpin, M.; Guillemin, D. (Orgs.). Language Description Informed by Theory. John Benjamins: Amsterdam, 2014. p. 337-357.

Moura, H; Berger, I. R. Verbos e satélites na língua inglesa. In: Moura, H; Mota, M; Santana, A. P. (Org.). Cognição, Léxico e Gramática. 1 ed. Florianópolis: Insular, 2012, p. 51-65.

Moura, H.; Silva Junior, I. "A representação do espaço nos verbos: os sentidos do movimento”. In: Aragão Neto, M; Cambrussi, M. (Orgs.). Léxico e Gramática: novos estudos de interface. $1^{\text {a }}$ ed. Curitiba: Editora CRV, 2014, p. 69-87.

Papafragou, A.; Massey, C.; Gleitman, L. When English proposes what Greek presupposes: The cross-linguistic encoding of motion. Cognition 98, 2006.

Rogers, T.; Mcclelland, J. Semantic cognition: a parallel distributed processing approach. London: MIT Press, 2004.

Rosch, E. Principles of categorization. In: Rosch, E.; Lloyd, B. B (Orgs.). Cognition and categorization. Hillsdale: Lawrence Erlbaum, 1978. p. 27-48.

Santos Filho, D. A expressão do modo de movimento no português brasileiro. Tese (Pós-Graduação em Linguística), UFSC, Florianópolis, 2018.

Santos Filho; Moura, H. Padrões de lexicalização no português brasileiro. Signo, v. 41, n. 71, set., 2016.

Slobin, D. From "thought and language" to "thinking for speaking". In: GUMPERZ, J. J.; LEVINSON, S. C. (Orgs.). Rethinking linguistic relativity. New York: Cambridge University Press, 1996a.(A) p. 70-96.

Slobin, D. Two ways to travel: verbs of motion in English and Spanish. In: SHIBATANI, M.; THOMPSON, S. A. (Orgs.). Grammatical constructions: their form and meaning. Oxford: Clarendon Press, 1996b. (B) p. 195-219.

Slobin, D. The universal, the typological and the particular in acquisition. In: SLOBIN, D. (Org.). The crosslinguistic study of language acquisition. London: Lawrence Erlbaum Associates, 1997. (C) 
Slobin, D. Language and thought online: cognitive consequences of linguistic relativity. In: GENTNER, D.; GOLDIN-MEADOW, S. (Orgs.). Language in mind: advances in the study of language and thought. Cambridge, MA: MIT Press, 2003. (D)

Slobin, D. The many ways to search for a frog: Linguistic typology and the expression of motion events. In: STRÖMQVIST, S.; VERHOEVEN, L. (Orgs.). Relating events in narrative: v. 02. Typological and contextual perspectives. Mahwah, NJ: Lawrence Erlbaum Associates, 2004.

Slobin, D. Relating Narrative Events in Translation. In: RAVID, D.; SHYLDKROT, H. B. (Orgs.). Perspectives on language and language development: Essays in honor of Ruth A. Berman. Dordrecht: Kluwer, 2005. (F)

Slobin, D. What makes manner of motion salient? Explorations in linguistic typology, discourse and cognition. In: HICKMANN, M.; ROBERT, S. (Orgs.). Space in Languages: Linguistic Systems and Cognitive Categories. Amsterdm/ New York, John Benjamins, 2006. (G) p. 59-82.

Talmy, L. Lexicalization patterns: Semantic structure in lexical forms. In: Timothy Shopen, ed. Language Typology and Syntactic Description, v. 03. Grammatical Categories and the Lexicon. Cambridge: Cambridge University Press. 1985, (A) p. $57-149$.

Talmy, L. Toward a Cognitive Semantics. Cambridge, MA: MIT Press. 2000. (B)

Talmy, L. The fundamental system of spatial schemas in language. In: Hampe, B. (Org.). From perception to meaning: image schemas in cognitive linguistics. Berlin: Mouton de Gruyter, 2006. (C)

Recebido em: 15/01/2019

Aceito em: 30/03/2019

Publicado em maio de 2019 